\title{
Seasonal Changes in Ice Distribution and Xylem Development in Blueberry Flower Buds
}

\author{
Cindy L. Flinn ${ }^{1}$ and Edward N. Ashworth ${ }^{2}$ \\ Department of Horticulture, Purdue University, West Lafayette, IN 47907 \\ Additional index words. Vaccinium corymbosum, 'Berkeley', highbush blueberry, freezing injury, $\mathrm{T}_{50}$, supercooling, \\ extraorgan freezing, xylem vessel elements
}

\begin{abstract}
The location of ice crystals and their relationship to xylem vessels was studied in nonacclimated and acclimated 'Berkeley' blueberry (Vaccinium corymbosum L.) flower buds. Light microscopy and low-temperature scanning electron microscopy (SEM) were used to detect ice crystals in the bud scales, floret scales, and bracts of dormant flower buds that had been frozen to-15C. No evidence of ice formation was observed in rachises, pedicels, and organs in florets when buds that had been fixed while frozen at $\mathbf{- 5 C}$ were examined with conventional SEM. This indicated that dormant buds underwent extraorgan freezing as a survival mechanism. Ice formation was not uniform in nonacclimated or deacclimated buds, although it was more prevalent in both than in acclimated buds. Large ice crystals were found in the ovaries of freezestressed nonacclimated buds. In deacclimated freeze-stressed buds, ice was found in the petals, rachises, pedicels, and ovaries. To determine whether this ice distribution pattern was correlated with the presence of mature xylem vessels, cleared flower buds were stained with basic fuchsin, which revealed the intact network of lignified elements. In nonacclimated buds (20 Sept.), mature xylem vessels extended through the rachises, connecting the bud scales with the floret scales and through the pedicels into the corollas of the florets. Although vascular development occurred in dormant buds, the greatest proliferation of vessels in the ovaries, petals, and sepals occurred coincident to the appearance of ice in these organs and the loss of hardiness.
\end{abstract}

When dormant flower buds of many woody species are cooled below $0 \mathrm{C}$, freezing occurs as one or more distinct temperaturedependent events, each exhibiting an exothermic reaction (Ashworth, 1990; Ashworth et al., 1989; George et al., 1974; Ishikawa and Sakai, 1985; Puckacki, 1987; Quamme, 1978; Sakai, 1982). The examined species exhibited a high-temperature exotherm just below $0 \mathrm{C}$, as extracellular water in the stem and bud froze. This was the only exotherm detected in winter buds of Prunus virginiana L., P. padus L. (Ashworth, 1984; Kader and Proebsting, 1992), and several coniferous species (Sakai, 1982). In conifer buds, needlelike ice crystals formed in the subtending crown tissues and not in the primordia (Sakai, 1982). In other species, such as peach $[P$. persica (L.) Batsch] (Ashworth, 1982; Ashworth et al., 1989; Quamme, 1978), Cornus officinalis Sieb. et Zucc. (Ishikawa and Sakai, 1985), cherry (P. cerasus L.) (Callan, 1990), and rhododendron (Rhododendron kosterianum Schneid.) (George et al., 1974), at least one more freezing event was detected between $-15 \mathrm{C}$ and $-30 \mathrm{C}$. This low-temperature exotherm occurred as supercooled water in the developing floral organs froze (Ashworth, 1982; Ashworth and Rowse, 1982; Callan, 1990; George al., 1974; Quamme, 1978). The location of this ice has been verified in peach (Ashworth et al., 1989) and 'Spectabilis Koehne' forsythia (Forsythia intermedia) (Ashworth, 1990) with scanning electron microscopy (SEM). These low-temperature exotherms coincided with the temperature at which lethal injury occurred.

The magnitude of ice crystals in C. officinalis bud scales and conifer crowns led Sakai (1982) to hypothesize that water from

\footnotetext{
Received for Publication 23 Feb. 1994. Accepted for publication 23 June 1994 Journal paper no. 14122 of the Purdue Univ. Agricultural Experiment Station. We thank Vicki Stirm and Tom Willard for technical assistance; Charles Bracker and Deb Sherman of the Purdue Univ. Electron Microscopy Center for their help and use of their facilities; and Robert Joly, Stanley Myers, and Mary Alice Webb for reviewing the manuscript. The cost of publishing this paper was defrayed in part by the payment of page charges. Under postal regulations, this paper therefore must be hereby marked advertisement solely to indicate this fact.

${ }^{1}$ Graduate research assistant.

${ }^{2}$ Associate professor; to whom reprint requests should be addressed.
}

nearby tissues, such as pistils and stamens, migrated toward the lower vapor pressure of ice in the scales and was thereby incorporated into the growing crystal. He coined the term extraorgan freezing to describe this phenomenon. Inverse-reciprocal changes in moisture content between $C$. officinalis floral organs and bud scales further corroborated his hypothesis (Ishikawa and Sakai, 1985). In species that exhibited only one exotherm, all freezable water was transferred from the floral organs to the ice crystals in the crowns. Low-temperature exotherms in supercooling species occurred when freezable water remaining in the floral organs spontaneously nucleated (George et al., 1974).

Why ice forms in some floral tissues and not in others is unclear, although developmental characteristics indicate that vascular development may be a key factor (Ashworth, 1982, 1984, 1990; Ashworth and Rowse, 1984; Ashworth et al., 1992; Kader and Proebsting, 1992). Dormant forsythia (Ashworth et al, 1992) and peach pistils (Ashworth, 1982, 1984) and stamens (Ashworth and Rowse, 1982), which lacked evidence of ice formation during a nonlethal freezing stress, also lacked xylem continuity with the parent plant. Xylem continuity between floral reproductive tissues and stem tissues occurred at about the same stage of bud hardiness at which lethal ice formation was observed in florets that had been exposed to $-5 \mathrm{C}$. This observation led researchers to hypothesize that the barrier that prevented ice formation in some tissues was a lack of xylem continuity with the rest of the plant. They theorized that such a barrier could prevent the propagation of ice into those tissues. To date, the relationship between ice distribution and vascular development has been studied only in the flower buds of species that exhibit a low-temperature exotherm. Highbush blueberry is a unique species in which to test this hypothesis since it lacks detectable low-temperature exotherms under slow cooling conditions (Flinn and Ashworth, 1994). We addressed the following questions: 1) How is ice distributed in frozen blueberry flower buds at various stages of hardiness? 2) At what stage of bud development do florets gain xylem continuity with subtending tissues? 3) Is the distribution of ice in blueberry flower buds a function of xylem development? 


\section{Materials and Methods}

Plant material. Terminal twigs of 'Berkeley' highbush blueberry were collected from Vander Molen's Blueberry Farm,
Rensselaer, Ind., during Winter 1990 at various stages of hardiness. A nonacclimated sample was collected in September before acclimation, several acclimated samples were collected monthly from December to March, and deacclimated samples were col-
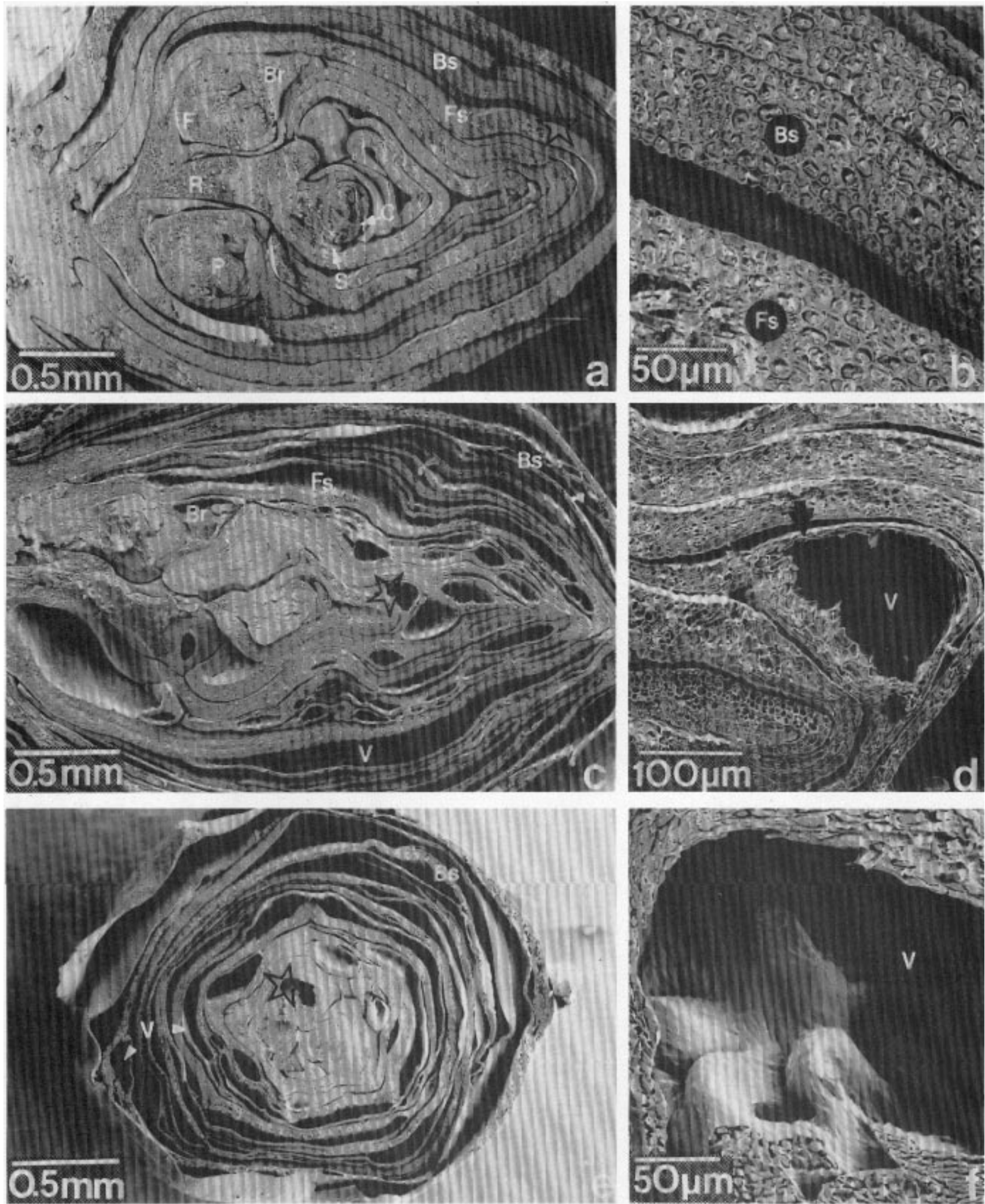

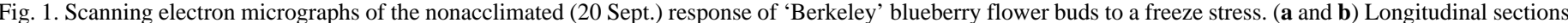

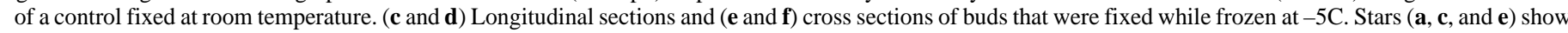

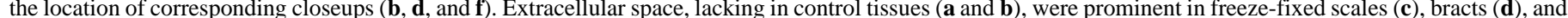
florets $(\mathbf{e}) . \mathrm{Br}=$ bract, $\mathrm{Bs}=$ bud scale, $\mathrm{C}=$ corolla, $\mathrm{F}=$ floret, $\mathrm{Fs}=$ floret scale, $\mathrm{P}=$ pistil, $\mathrm{R}=\mathrm{rachis}, \mathrm{S}=$ sepal, $\mathrm{V}=\mathrm{void}$. 
lected biweekly from 21 Mar. to full bloom. Freshly harvested twigs were sealed in plastic bags, packed in ice, and transported to the laboratory within $2 \mathrm{~h}$ of collection. Upon arrival at the laboratory, some specimens were used in experiments immediately, while the rest were resealed in bags and stored at $4 \mathrm{C}$ for $5 \mathrm{~h}$. Unless otherwise stated, specimens were processed immediately before each experiment by removing leaves and cutting twigs into $3-\mathrm{cm}$ segments, each with three to five flower buds.

Hardiness evaluations. Flower bud hardiness was assessed in controlled freezing tests as described previously (Flinn and Ashworth, 1994). Processed twigs were cooled in vacuum flasks to temperatures that were selected to yield $0 \%$ to $100 \%$ bud mortality. Each flask contained 12 twigs. An adaptation of the Spearman-Kärber equation (Bittenbender and Howell, 1974) was used to calculate the temperature at which $50 \%$ ovarian death occurred $\left(\mathrm{T}_{50}\right)$.

Location of ice crystals. Dormant processed twigs, enclosed in a foil packet lined with damp paper towels, were sealed in a vacuum flask and placed in a $-20 \mathrm{C}$ freezer for $24 \mathrm{~h}$. Frozen buds were bisected and then examined with a light microscope.

Low-temperature SEM was used to confirm the presence of ice in the buds. This method was adapted for flower buds from a technique previously used with stem tissues (Malone and Ashworth, 1991) and wheat leaves (Pearce and Ashworth, 1992). Dormant processed twigs were frozen two ways. Freeze-stressed buds were enclosed in a foil packet lined with damp paper towels, sealed in a vacuum flask, and cooled to $-15 \mathrm{C}$ at about $-5 \mathrm{C} / \mathrm{h}$ in a walk-in freezer. While at $-15 \mathrm{C}$, whole buds were excised and mounted on SEM specimen stubs, with the long axis of the bud perpendicular to the stub. The base of the bud was placed into holes drilled in the SEM stub and held in place with a cryoadhesive (Tissue-Tek; Miles Diagnostic Division, Elkhart, Ind.) plus carbon. The frozen, mounted tissue was quench-frozen and stored in liquid N. Mounted control buds were plunged unfrozen into liquid N. Specimens were transferred to the SEM cryochamber as described by Malone and Ashworth (1991) and fractured cross-sectionally. The cleaved buds were then moved to the cold stage where they were either viewed with ice crystals in situ at 1 to $2 \mathrm{kV}$ or etched, coated with gold palladium, and viewed at $10 \mathrm{kV}$.

To view frozen buds without the obstruction of ice crystals, frozen tissues were preserved using isothermal freeze fixation (MacKenzie et al., 1975) as adapted for flower buds (Ashworth, 1990; Ashworth et al., 1989; Warmund et al., 1992). On each harvest date, 10 processed twigs were slowly cooled to $-5 \mathrm{C}$ in sealed glass test tubes and fixed in $8 \%$ formaldehyde for 7 days at $-5 \mathrm{C}$. Controls were fixed simultaneously at room temperature in formalin-acetic acid-alcohol (FAA) (Johansen, 1940). Buds were then dehydrated using a graded series of ethanol, bisected, and critical-point dried. Specimens were then mounted and sputtercoated with gold palladium for examination with a scanning electron microscope (JSM-840; JEOL, Tokyo).

Location of mature xylem vessel elements. Five FAA-preserved flower buds from each collection date were dehydrated in $50 \%$ aqueous ethanol. Bud scales, floret scales, and bracts were then removed, and intact inflorescences and excised florets were placed into 20-ml syringes that had been modified to serve as a containerized staining system for small samples $>250 \mu \mathrm{m}$ in diameter (Claassen and Zasoski, 1992). Plant material was then incubated in $5 \%$ aqueous sodium hydroxide at room temperature for $12 \mathrm{~h}$. After triple-rinsing in deionized water, samples were placed in $2.6 \%$ aqueous sodium hypochlorite until opaque brown tissues were translucent yellow. After triple-rinsing in deionized water for 10 min, the cleared inflorescences were stained with basic fuchsin (Fisher Scientific, Fair Lawn, N.J.) using Fuchs' (1963) Method 4 starting with step 3 . Fuchsin-stained tissues were then counterstained in $1 \%$ ethanolic fast green for 30 min between steps 8 and 9. They were then rinsed with absolute ethanol until tissues were the desired intensity of green before continuing with Fuchs' (1963) procedure. The stained, cleared samples were then mounted in Permount (Fisher Scientific) and viewed with a light microscope.

\section{Results}

Flower bud development and hardiness. Blueberry inflorescences appeared during late summer on terminal sections of the current season's growth. Each inflorescence contained 10 to 13 subsessile florets that radiated from a central axis in a racemose arrangement. Each bud also contained a series of scales: the entire inflorescence was enfolded by four pairs of bud scales andeachfloret was encircled first by a pair of bracts and then a floret scale (Fig. 1a).

Nonacclimated buds were not cold hardy, as indicated by $100 \%$ bud mortality observed at $-5 \mathrm{C}$ in laboratory freezing tests (Fig. 2). Each floret bore a rudimentary pistil, filaments, sepal buttresses, and corolla (Fig. 1a). Bracts, scales (Fig. 1b), and floret tissues were composed of densely packed cells and lacked extracellular space (Fig. 1a).

By 18 Dec., buds were $25 \%$ larger than in September and, with $\mathrm{a} \mathrm{T}_{50}$ of $-23 \mathrm{C}$, were the hardiest of the collected samples (Fig. 2). Bud hardiness remained at temperatures below -20C through February. By 27 Feb., filaments, anthers, and tapetum were evident in the stamens, and rudimentary styles and ovules comprised the pistils (Fig. 3).

Two weeks later, the $\mathrm{T}_{50}$ increased sharply, signaling the onset of deacclimation (Fig. 2). By 18 Apr., buds could be killed by temperatures of $-5 \mathrm{C}$. At this time, pedicels had elongated and florets had expanded beyond the bracts and scales (Fig. 4a). Welldeveloped anthers were filled with pollen grains. Long pistillate styles were subtended by ovaries with well-developed ovules in large locules (Fig. 4b).

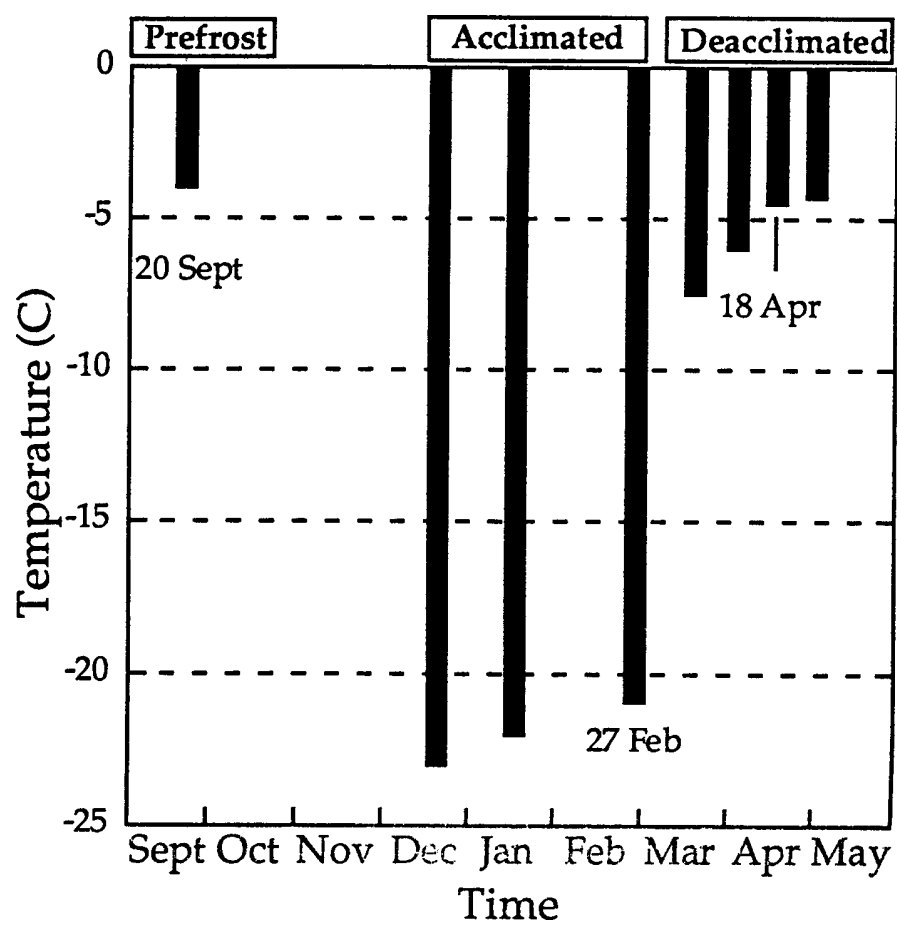

Fig. 2. 'Berkeley' blueberry flower bud hardiness as determined by $\mathrm{T}_{50}$ during the 1990 91 season. Collection dates are grouped by seasonal markers in flower bud hardiness. 

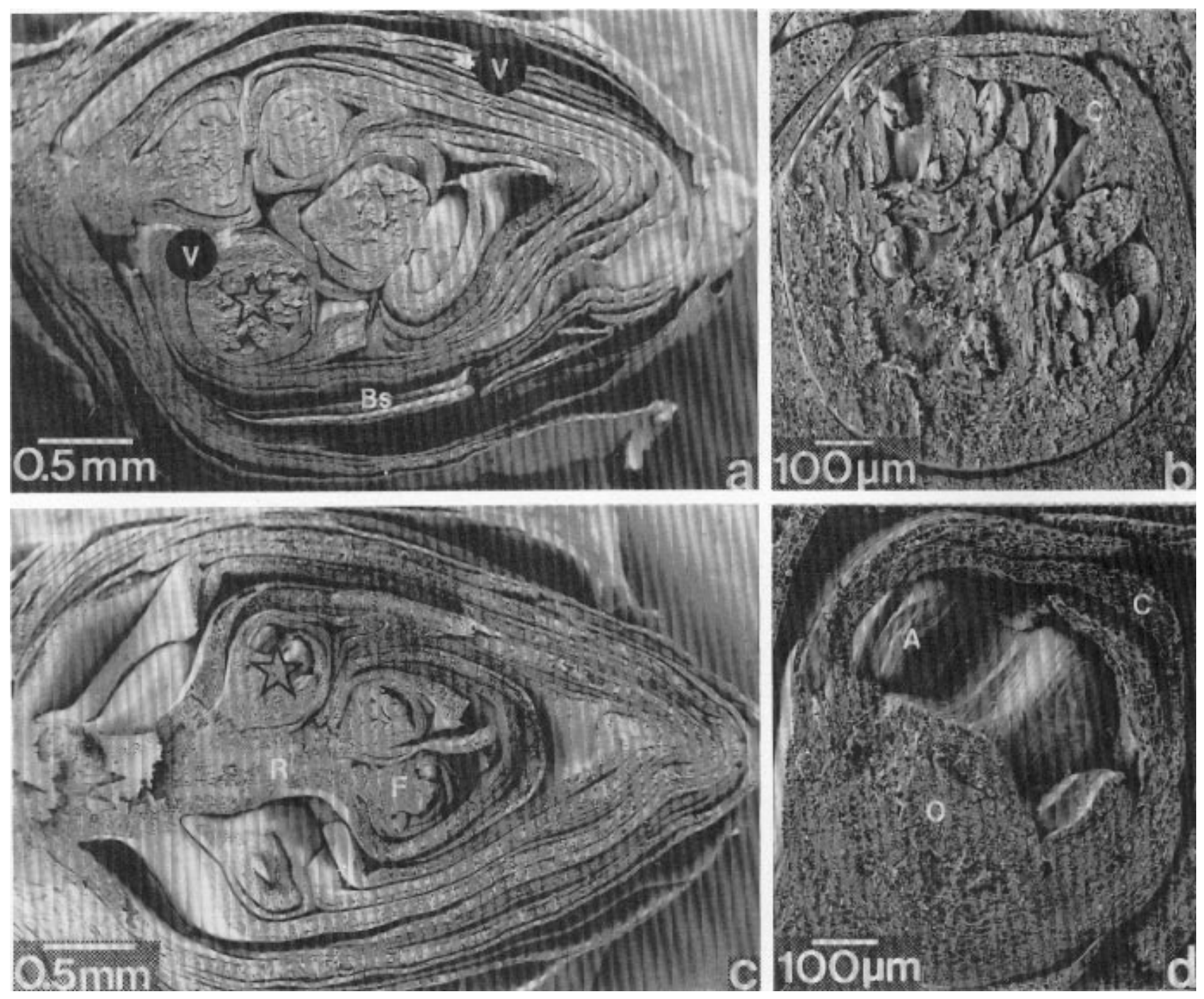

Fig. 3. Scanning electron micrographs of the acclimated (27 Feb.) response of blueberry flower buds to a freeze stress. Longitudinal sections of a control bud fixed at room temperature (a and $\mathbf{b})$ and a bud that was fixed while frozen at $-5 \mathrm{C}(\mathbf{c}$ and $\mathbf{d})$. Stars ( $\mathbf{a}$ and $\mathbf{c})$ mark the location of corresponding closeups $(\mathbf{b}$ and $\mathbf{d})$. Freeze-fixed buds (c and $\mathbf{d}$ ), like control buds ( $\mathbf{a}$ and $\mathbf{b}$ ), had voids in scales and bracts but not in florets. $\mathrm{A}=$ anther, $\mathrm{Bs}=$ bud scale, $\mathrm{C}=$ corolla, $\mathrm{F}=$ floret, $\mathrm{O}=$ ovary, $\mathrm{R}=$ rachis, $\mathrm{V}=\mathrm{void}$

One anatomical feature detected in acclimated (Fig. 3a) and deacclimated (Fig. 4a) buds, but not in nonacclimated buds (Fig. $1 \mathrm{a}$ and $\mathrm{b}$ ), was long narrow extracellular splits in bud scales, floret scales, and bracts. When viewed in cross-section, the splits appeared to radiate outward from the midrib toward the edges of these organs, separating the cells into two to three layers. These voids, first detected in December, persisted throughout the winter and into spring (Fig. 4a). Voids were not detected in the florets (Fig. $3 \mathrm{~b}$ and $4 \mathrm{~b}$ ), pedicels, or rachises during the same period, although after $18 \mathrm{Apr}$. large voids were detected in the sepals of the expanding florets (Fig. 4b).

Ice distribution. Ice distribution in dormant blueberry buds was examined using several techniques to determine whether fissures in floral organs were similarly created. In the first method, frozen buds were bisected and examined for ice with a light microscope. Large ice crystals were detected in the bud scales despite limited contrast and magnification. As the ice melted, large pockets or lacunae, similar to those seen in fixed acclimated buds, remained where the ice had been.

We then used low-temperature SEM to examine further the location of ice in greater detail. Field-acclimated buds were either plunged unfrozen into liquid $\mathrm{N}$ (controls) or cooled slowly to $-15 \mathrm{C}$ and then placed frozen into liquid $\mathrm{N}$ (freeze-stressed). After fracturing, the buds were examined for ice before, during, and after sublimation as outlined by Ashworth et al. (1988), Malone and Ashworth (1991), Pearce (1988), and Pearce and Ashworth (1992). During this process, only ice can be gradually but completely etched away when the stage temperature is elevated from -180 to $-60 \mathrm{C}$. Areas that contained voids only after sublimation were those that had contained ice before sublimation (Ashworth et al., 1988; Malone and Ashworth, 1991; Pearce, 1988; Pearce and Ashworth, 1992).

Anatomical features of freeze-stressed blueberry buds were difficult to discern because ice filled most of the extracellular spaces (Fig. 5 a and c). Sublimation of the same specimen revealed bud scales riddled with expansive extracellular voids (Fig. $5 \mathrm{~b}$ and d). As in conventionally fixed acclimated buds (Fig. 3a), the voids appeared to radiate from vascular bundles outward toward the edges of the scales (Fig 5b). Cells flanking the voids were compressed as though they had collapsed under extracellular force (Fig. 5e). In sharp contrast to unetched, freeze-stressed buds (Fig. $5 \mathrm{a}$ and $\mathrm{c}$ ), the unetched fracture faces of controls appeared 

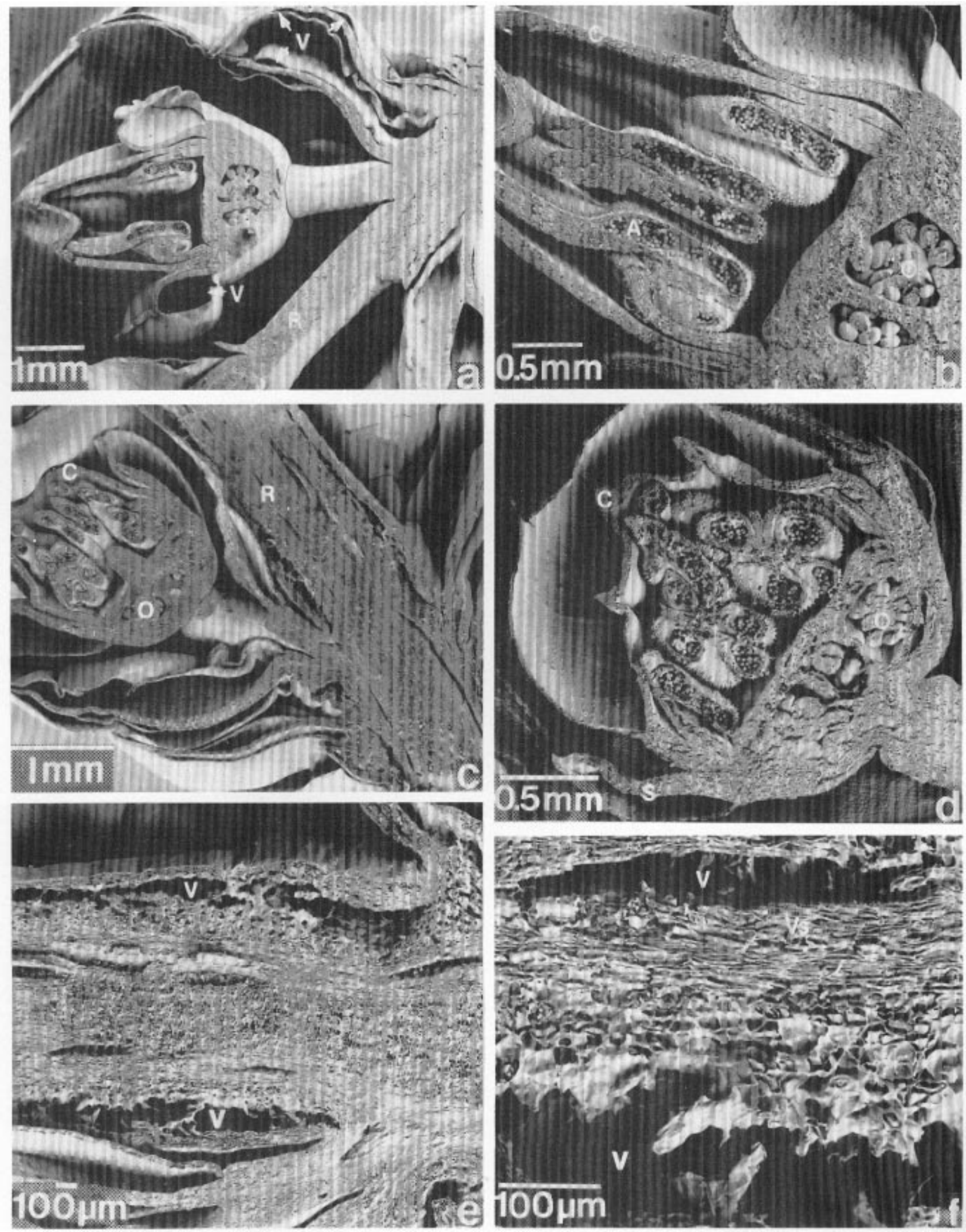

Fig. 4. Scanning electron micrographs of the deacclimated (18 Apr.) response of blueberry flower buds to a freeze stress. Longitudinal sections of a control bud fixed at room temperature (a and $\mathbf{b})$ and a bud fixed while frozen at $-5 \mathrm{C}(\mathbf{c}-\mathbf{f})$. Voids in bracts, scales, and sepals of the control (a and $\mathbf{b})$ were the result of repeated freezethaw cycles in the field. Voids in the florets $(\mathbf{c}$ and $\mathbf{d})$ and rachis $(\mathbf{e}$ and $\mathbf{f})$ of freeze-fixed buds were created by exposure to $-5 \mathrm{C}$ during fixation. $\mathrm{A}=$ anther, $\mathrm{C}=$ corolla, $\mathrm{O}=$ ovary, $\mathrm{R}=$ rachis, $\mathrm{S}=$ sepal, $\mathrm{V}=$ void, $\mathrm{Vs}=$ vascular strands 

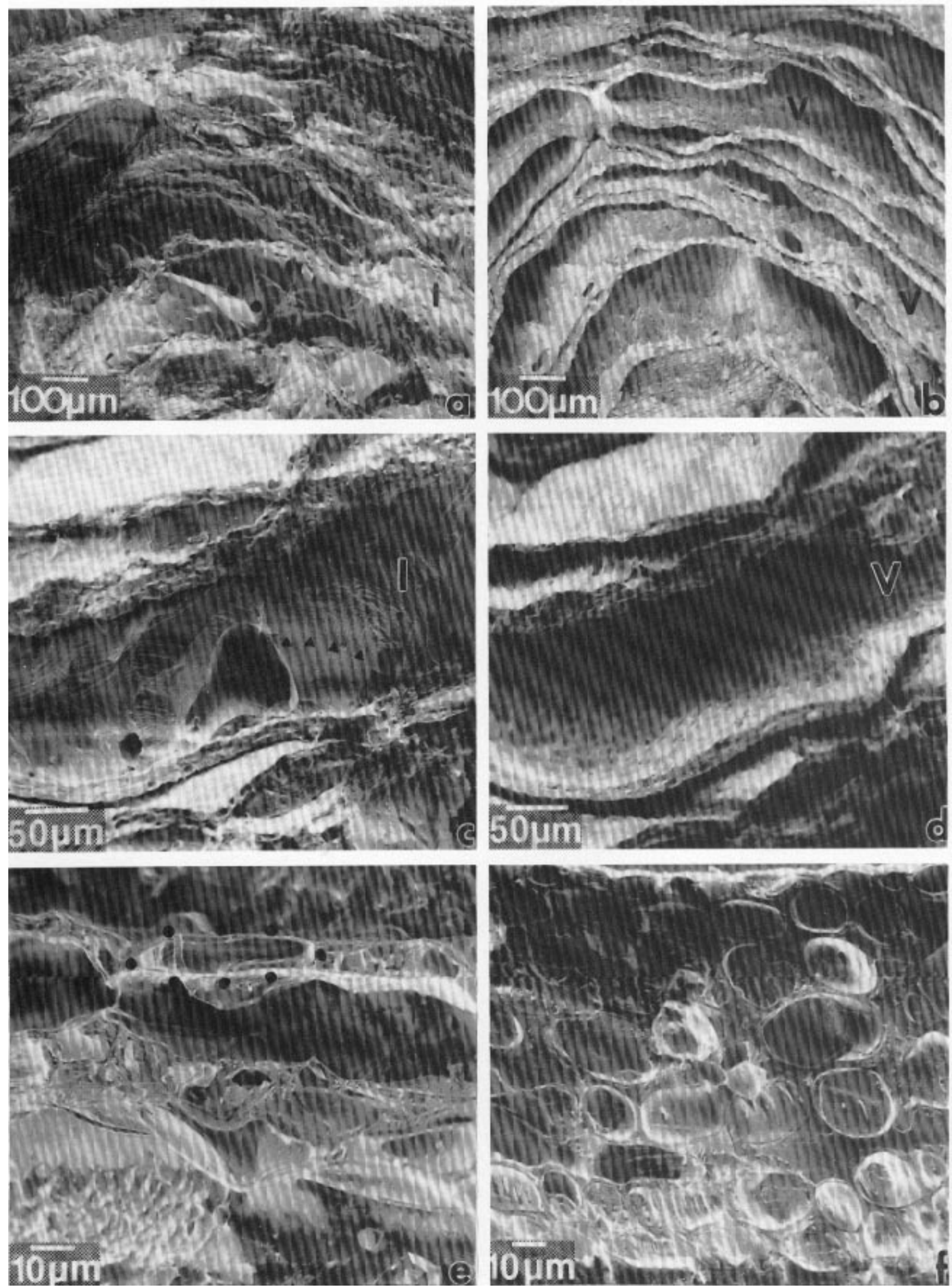

Fig. 5. Location of ice crystals in acclimated blueberry flower buds. Low-temperature scanning electron micrographs of the fractured surfaces of freeze-stressed buds (ae) and a control (f). The location of ice was determined by comparing a specimen before (a) and after (b) sublimation. The large voids in $\mathbf{b}$ that appeared after sublimation were where ice crystals were in a. A closeup of a bud scale before (c) and after (d) sublimation demonstrates that ice resided in the bud scales. The presence of conchoidal planes (black dots in a) and stipples (black triangles in c) were also characteristics used to identify ice crystals. Cells of etched, freeze-stressed buds (outlined with black dots in $\mathbf{e}$ ) were collapsed. In etched controls (f), cells were round and plump. I = ice, V = void. 
identical to those of conventionally fixed buds (Fig. 5f). Bud scales were comprised of plump, round cells with narrow, extracellular fissures, and, unlike freeze-stressed buds, sublimation had no effect on their appearance. Therefore, ice accumulation in extracellular voids (Fig. $5 \mathrm{a}$ and c) seemed to be a phenomenon associated with freezing stress.

Ice distribution in florets and other bud tissues was examined in nonacclimated, acclimated, and deacclimated buds with isothermal freeze fixation. Tissues fixed with this technique retained voids where ice had been (Ashworth, 1990; Ashworth et al., 1989). The effects of the $-5 \mathrm{C}$ freeze stress were evaluated by comparing freeze-fixed buds to their counterparts that had been fixed at room temperature. Freeze-fixed nonacclimated buds were riddled with voids that extended throughout the bud scales, floret scales, and bracts (Fig. $1 \mathrm{c}$ and e). As in acclimated buds, the voids appeared to radiate from vascular bundles (Fig. 1e). The extent of compacted and ruptured cells surrounding the voids was visibly greater in freeze-fixed, nonacclimated buds (Fig. 1d) than on any other date. Large voids also extended through the center of floret gynoeciums (Fig. 1f). Voids were not detected in nonacclimated buds that had been fixed in FAA or isothermal fixation solution at room temperature. The voids seen in freeze-fixed nonacclimated buds, therefore, resulted from the applied freezing stress and were not artifacts of the fixation protocol.

Acclimated buds did not seem to be affected by freeze fixation at $-5 \mathrm{C}$. Voids detected in the bud scales, bracts, and floret scales (Fig. $3 \mathrm{c}$ and d) were similar to those seen in acclimated buds fixed at room temperature (Fig. $3 \mathrm{a}$ and $\mathrm{b}$ ) and those examined with lowtemperature SEM (Fig. 5 b and d). These voids were likely created by freezing episodes in the field. Voids were not detected in the florets, pedicels, or rachises of freeze-fixed acclimated buds (Fig. 3d).

Although voids created in the scales and bracts of acclimated buds persisted throughout deacclimation, voids were detected in other tissues when deacclimated buds were exposed to $-5 \mathrm{C}$ (Fig. $4 \mathrm{c}-\mathrm{f}$ ). Voids resulting from ice formation, evident in deacclimated florets, ranged from large splits in the corollas to small tissue disruption in filaments, ovaries (Fig. 4d), and pedicels (Fig. 4c). Cellular disruptions noted in rachises (Fig. 4e) were typically adjacent to the strands of mature xylem vessels (Fig. 4f).

Although the location of ice accumulation changed as bud hardiness changed, ice was not evenly distributed in any of the specimens examined. The temperature at which voids could be seen in florets was hardiness dependent and coincided with lethal low-temperature injury.

Vascular development. Xylem development was monitored in nonacclimated, acclimated, and deacclimated buds with a fuchsinbased stain procedure. Using this technique, the network of mature xylem vessels in a cleared plant organ could be viewed in its entirety with the aid of a light microscope (Fuchs, 1963).

Continuous strands of fuchsin-stained xylem extended through the rachises into the bract and scales of nonacclimated buds (Fig. 6a). Several strands of lignified elements continued upward through pedicels and into florets (Fig. 6a). Eight to twelve strands, each $\approx 4$ $\mu \mathrm{m}$ in diameter, extended into the lower third of corollas. Vascular traces in pistils, filaments, and the distal portions of corollas on this date had not fully differentiated. The strands in these regions were composed of elongated procambial cells that lacked secondary wall thickenings and, therefore, were not stained with fuchsin.

By December, florets (Fig. 6b) were $\approx 1.7$ times wider and two times longer than nonacclimated florets. Continuous mature vessels had also differentiated farther toward the apex of floret corollas. In six florets of the five buds examined, some strands of fuchsin-stained xylem were seen curved along the inner perimeter
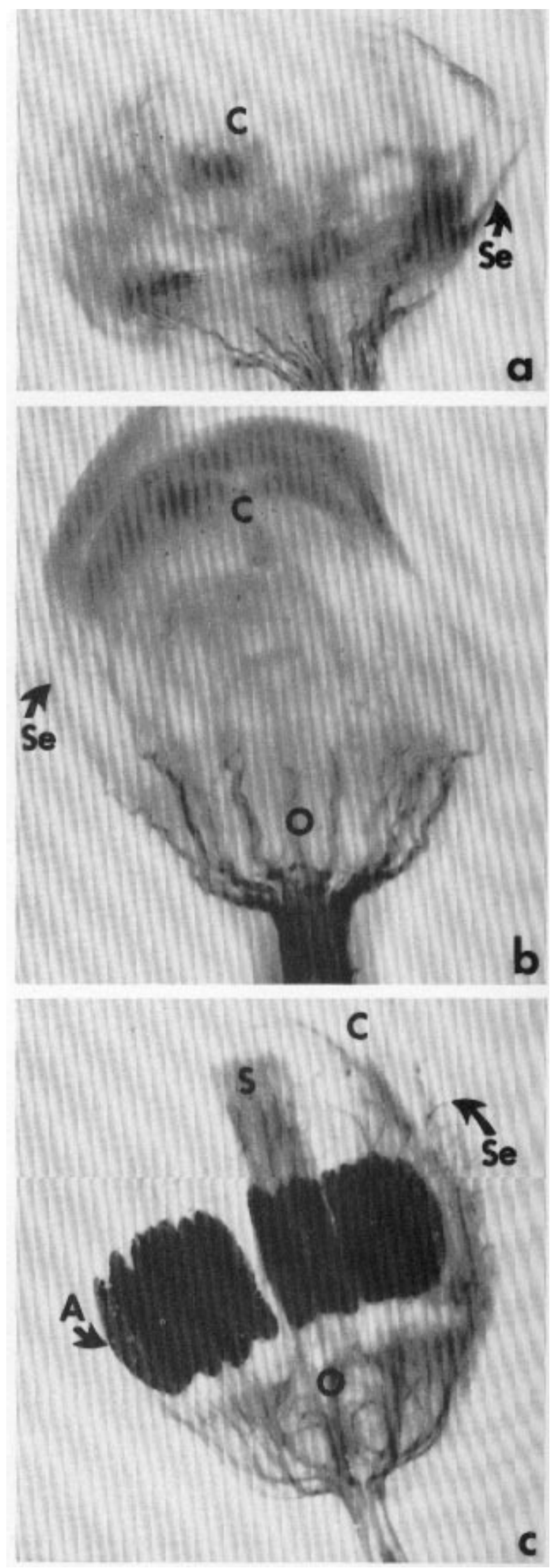

Fig. 6. Light micrographs of the intact network of xylem vessels with darkly stained lignified secondary wall thickenings in cleared blueberry florets. Florets are (a) nonacclimated (20 Sept.), (b) acclimated (18 Dec.), and (c) deacclimated (18 Apr.). A = anthers, $\mathrm{C}=$ corolla, $\mathrm{S}=$ style, $\mathrm{Se}=$ sepal, $\mathrm{O}=$ ovary. Scale: $\mathbf{a}=160 \times, \mathbf{b}=90 \times, \mathbf{c}=23 \times$. 
of floret ovaries. Vascular strands in the style, ovules, and anther were comprised of unstained, undifferentiated procambial cells. Floret size and vascular development remained stagnant through the end of February.

By 18 Apr., bud and vascular development had resumed (Fig. $6 c)$. Deacclimated florets were four times longer and wider than acclimated florets. A densely stained vascular system spread throughout the florets. Mature xylem formed a network throughout corollas. Continuous strands extended from pedicels to ovules in ovaries and upward through filament and styles. All portions of the florets appeared to be connected to the parent plant with mature xylem.

\section{Discussion}

Several theories have been proposed to explain the preferential accumulation of ice in some flower bud tissues but not in others.

One theory hypothesized that differences in water potentials among the tissues could cause localized ice formation (Ishikawa and Sakai, 1985; Quamme, 1978). Another theory proposed that ice formation was the result of intrinsic ice nucleators and that the nucleators were present in ice-accumulating tissues and absent in ice-free tissues (Ishikawa and Sakai, 1985). One other theory proposed that morphology and vascular development dictated the tissues in which ice crystals would accumulate (Ashworth, 1984; Ashworth et al., 1989, 1992; Callan, 1990; Kader and Proebsting, 1992). The lack of low-temperature exotherms in differential thermal analysis profiles of slowly cooled blueberry flower buds (Flinn and Ashworth, 1994) indicated that further understanding of ice segregation in flower buds might be gained by an investigation of how bud hardiness and vascular development influence ice location in blueberry flower buds.

Similar to the patterns of ice distribution reported in flower buds of other species (Ashworth, 1990; Ashworth et al., 1989; Ishikawa and Sakai, 1985; Sakai, 1982; Warmund et al., 1992; Weigand, 1906), ice was not uniformly distributed in blueberry flower buds. The first freezing episode resulted in the formation of extracellular pockets in blueberry bud scales, floret scales, and bracts (Fig. 3a). These voids apparently served as preferential sites of ice accumulation during subsequent freezing episodes. The accumulation of ice in scales and bracts did not affect the bud's survival. The temperature at which ice formed in the florets varied with hardiness, as did the temperature of lethal injury. Buds unable to tolerate $-5 \mathrm{C}$ exhibited voids in florets (Figs. $1 \mathrm{c}$ and $\mathrm{e}$ and $4 \mathrm{c}-\mathrm{e}$ ). Acclimated buds, which survived temperatures below $-5 \mathrm{C}$, did not exhibit ice formation in florets (Fig. $3 \mathrm{a}-\mathrm{d}$ ).

Vascular development in blueberry flower buds was similar to that reported in $P$. virginiana and $P$. padus. Xylem continuity between blueberry florets and the parent plant's vascular system occurred as early as September (Fig. 6a). Although the vascular strands in the pistils and stamens were comprised of undifferentiated procambial cells, lignified elements in the pedicels connected the lower edges of corollas with those in the rachises. From September to December, mature xylem progressed toward the apex of corollas and curved inward into ovaries (Fig. 6b). Vascular development then appeared to be stagnant until deacclimation. By 18 Apr., every floral organ appeared to be connected to the parent plant with mature xylem strands.

The observation of a continuous conduit of mature xylem vessels between nonacclimated florets and the parent plant was inconsistent with the earlier stated hypothesis that a continuous conduit of xylem into a tissue would allow ice propagation and would thereby dictate which tissues would be sites of ice accumulation. For some tissues the hypothesis seemed to be true. Accli- mated bud scales, floret scales, and bracts, which accumulated ice, were connected to the parent plant's vascular system with strands of mature xylem. Fissures in these tissues appeared to radiate from vascular bundles, indicating that ice in these tissues may have been seeded through the xylem. However, pedicels, rachises, and the lower portion of corollas, which were vascularly linked to xylem in the stem as early as September, did not form ice until buds had deacclimated in the spring. Therefore, a barrier other than the lack of mature xylem was responsible for ice distribution patterns observed in blueberry flower buds.

Ice could have propagated through the xylem in the rachis to the bud scales and through the pedicels into blueberry corollas, but there was no evidence of ice formation in the florets, pedicels, or rachises until after buds had deacclimated. We were not able to conclude why or how water could migrate from the floret to the growing ice crystals in the bud scales if a continuous column of water was present in the xylem vessels that connected the two. The voids of acclimated buds (Fig. 3a) were narrower than the voids of freeze-fixed nonacclimated (Fig. $1 \mathrm{c}$ and d) or deacclimated buds (Fig. 4 b-d), evidence that the moisture content of blueberry buds decreased during acclimation, as reported by Bittenbender and Howell (1975). Reduced moisture content during acclimation has been observed in other species as well (Andrews and Proebsting, 1987; Ishikawa and Sakai, 1985; Lumis et al., 1972; Quamme, 1983). Therefore, one explanation might be that water in the florets, pedicels, and rachises froze, but the quantity of ice was so small that it did not form extracellular voids as it did in the scales or bracts and would have been undetectable with the methods used. Another possibility is that the vessels in the floret and rachis were empty and lacked enough residual moisture to effectively propagate ice crystals, thus isolating the florets from nucleation. The exact explanation is unclear at this time.

\section{Conclusions}

From the observations in this study, we know that ice is not evenly distributed in dormant blueberry flower buds. It accumulates in the bud scales, floret scales, and bracts, creating large cavities. Rachises, florets, and pedicels were devoid of evidence of ice formation in dormant buds. However, the location of ice was influenced by hardiness. Ice formed readily in nonhardy florets in nonacclimated and deacclimated buds. Ice was also detected in the rachises and pedicels of deacclimated buds. Ice distribution was not related to the distribution of mature xylem vessels. This was demonstrated by the presence of mature vessels in the rachises, pedicels, and corolla in dormant buds without evidence of ice.

\section{Literature Cited}

Andrews, P.K. and E.L. Proebsting. 1987. Effects of temperature on the deep supercooling characteristics of dormant and deacclimating sweet cherry flower buds. J. Amer. Soc. Hort. Sci. 112:334-340.

Ashworth, E.N. 1982. Properties of peach flower buds which facilitate supercooling. Plant Physiol. 70:1475-1479.

Ashworth, E.N. 1984. Xylem development in Prunus flower buds and the relationship to deep supercooling. Plant Physiol. 74:862-865.

Ashworth, E.N. 1990. The formation and distribution of ice within Forsythia flower buds. Plant Physiol. 92:718-725.

Ashworth, E.N. and D.J. Rowse. 1982. Vascular development in dormant Prunus flower buds and its relationship to supercooling. HortScience 17:790-791.

Ashworth, E.N., G.A. Davis, and M.E. Wisniewski. 1989. The formation and distribution of ice within dormant and deacclimated peach flower buds. Plant Cell Environ. 12:521-528.

Ashworth, E.N., T.J. Willard, and S.R. Malone. 1992. The relationship 
between vascular differentiation and the distribution of ice within forsythia flower buds. Plant Cell Environ. 15:507-612.

Ashworth, E.N., P. Echlin, R.S. Pearce, and T.L. Hayes. 1988. Ice formation and tissue response in apple twigs. Plant Cell Environ. 11:703-710.

Bittenbender, H.C. and G.S. Howell. 1974. Adaptation of the SpearmanKärber method for estimating the $\mathrm{T}_{50}$ of cold stressed blueberry flower buds. J. Amer. Soc. Hort. Sci. 99:187-190.

Bittenbender, H.C. and G.S. Howell. 1975. Interactions of temperature and moisture content on spring deacclimation of flower buds of highbush blueberry. Can. J. Plant Sci. 55:447-452.

Callan, N.W. 1990. Dormancy effects on supercooling in deacclimated 'Meteor' tart cherry flower buds. J. Amer. Soc. Hort. Sci. 115:982-986.

Claassen, V.P. and R.J.Zasoski. 1992. A containerized staining system for mycorrhizal roots. New Phytol. 121:49-51.

Flinn, C.L. and E.N. Ashworth. 1994. Blueberry flower bud hardiness is not predicted by differential thermal analysis. J. Amer. Soc. Hort. Sci. 119:295-298.

Fuchs, C. 1963. Fuchsin staining with $\mathrm{NaOH}$ clearing for lignified elements of whole plants or plant organs. Stain Technol. 38:141-144.

George, M.F., M.J. Burke, and C.J. Weiser. 1974. Supercooling in overwintering azalea flower buds. Plant Physiol. 54:29-35.

Ishikawa, M. and A. Sakai. 1985. Extraorgan freezing in wintering flower buds of Cornus officinalis Sieb. et Zucc. Plant Cell Environ. 8:333-338. Johansen, D.A. 1940. Plant microtechnique. McGraw-Hill, New York. Kader, S.A. and E.L. Proebsting. 1992. Freezing behavior of Prunus, subgenus Padus, flower buds. J. Amer. Soc. Hort. Sci. 117:955-960.

Lumis, G.P., R.A. Mecklenburg, and K.C. Sink. 1972. Factors influencing winter hardiness of flower buds and stems of evergreen azaleas. J. Amer. Soc. Hort. Sci. 97:124-127.

MacKenzie, A.P., T.A. Kuster, B.J. Luyet. 1975. Freeze-fixation at high subzero temperatures. Cryobiology 8:420-430.

Malone, S.R. and E.N. Ashworth. 1991. Freezing stress response in woody tissues observed using low-temperature scanning electron microscopy and freeze substitution techniques. Plant Physiol. 95:871-881.

Pearce, R.S. 1988. Extracellular ice and cell shape in frost-stressed cereal leaves: A low-temperature scanning-electron-microscopy study. Planta 175:313-324.

Pearce, R.S. and E.N. Ashworth. 1992. Cell shape and localisation of ice in leaves of overwintering wheat during frost stress in the field. Planta 188:324-331.

Pukacki, P. 1987. Deep supercooling of shoot and bud tissues of Picea abies. For. Ecol. Mgt. 20:97-103.

Quamme, H.A. 1978. Mechanism of supercooling in overwintering peach flower buds. J. Amer. Soc. Hort. Sci. 103:57-61.

Quamme, H.A. 1983. Relationship of air temperature to water content and supercooling of overwintering peach flower buds. J. Amer. Soc. Hort. Sci. 108:697-701

Sakai, A. 1982. Extraorgan freezing of primordial shoots of winter buds of conifers, p. 199-209. In: P.H. Li and A Sakai (eds.). Plant cold hardiness and freezing stress. vol. 2. Academic Press, New York.

Warmund, M.R., F. Takeda, and G.A. Davis. 1992. Supercooling and extracellular ice formation in differentiating buds of eastern thornless blackberry. J. Amer. Soc. Hort. Sci. 117:941-945.

Weigand, K.M. 1906. Some studies regarding the biology of buds and twigs in winter. Bot. Gaz. 41:373-424. 